\title{
Effect of isostretching on the quality of life of incontinent older women
}

\author{
Efeito do isostretching sobre a qualidade \\ de vida de idosas incontinentes
}

\section{Luana Weigert Kachorovski ${ }^{[a]}$, Célia Cristiani Slongo Moraes ${ }^{[a]}$, Evelin de Moura Rosa ${ }^{[a]}$, Cristiane Regina Gruber ${ }^{[b] *}$}

[a] Faculdades Integradas do Brasil (UniBrasil), Curitiba, PR, Brazil

[b] Universidade Tecnológica Federal do Paraná (UTFPR), Curitiba, PR, Brazil

\begin{abstract}
Introduction: Urinary incontinence (UI) can be defined as a brief involuntary loss of urine. It is a hygienic and social problem that affects mainly older women and contributes to reduced quality of life (QoL). There are currently several therapeutic strategies available for the treatment of UI, including the method of Isometric Stretching, which is based on balance exercises that lead to greater flexibility and stronger joints, tendons and muscles. Objective: To investigate the effect of Isometric Stretching on the QoL of 10 institutionalized older women with complaint of UI. Materials and methods: We used the ICIQ-SF to assess women's QoL pre- and post-treatment. The study duration was 12 weeks. Results: $80 \%$ of the women showed a significant improvement in UI ( $p=0.007061)$ and QoL $(p=0.011)$. Conclusion: We concluded
\end{abstract}

* LWK: grad, e-mail: luana_weigert@hotmail.com CCSM: grad, e-mail: celiacristiani@hotmail.com EMR: grad, e-mail: evy.mr@hotmail.com CRG: MSc, e-mail: cristiane_gruber@hotmail.com 
that Isometric Stretching contributed to a significant improvement in urinary incontinence symptoms and quality of life in incontinent older women.

Keywords: Physical therapy. Urinary incontinence. Quality of life.

\section{Resumo}

Introdução: A incontinência urinária (IU) pode ser definida como a perda involuntária de urina. Constitui um problema higiênico e social e afeta principalmente mulheres idosas, contribuindo para a redução da qualidade de vida $(Q V)$. Atualmente existem diversos recursos terapêuticos para o tratamento da IU, dentre eles o método Isostretching, que é baseado em uma cinesioterapia de equilíbrio flexibilizando as partes rígidas e fortalecendo as debilitadas. Objetivo: Verificar a influência de exercícios baseados nos princípios do método Isostretching sobre a QV de 10 idosas institucionalizadas com queixa de IU. Materiais e métodos: O questionário ICIQ-SF foi aplicado para avaliação da QV no início e ao término da pesquisa que teve duração de 12 semanas. Resultados: Houve melhora significativa da IU ( $p$-valor = 0,007061) e da QV ( $p$-valor =0,011) para 80\% das idosas. Conclusão: Considerando os resultados obtidos, o método contribuiu para a melhora significativa dos sintomas da IU e consequentemente da QV das idosas incontinentes.

Palavras-chave: Fisioterapia. Incontinência urinária. Qualidade de vida.

\section{Introduction}

Urinary incontinence (UI) can be defined as impairment of the normal mechanisms of storage and disposal of urine (1). According to the International Continence Society (ICS) (2), UI is an "objectively demonstrable, involuntary loss of urine $(50 \mathrm{ml} /$ day, not less frequent than once every two weeks) that results in a social and/or hygienic problem".

Silva and Lopes (3) state that UI can be classified into: stress (loss of uring during exercise, coughing or sneezing); urge (when there is an involuntary loss of urine upona sudden urge); and mixed (when features of both stress and urge incontinence are present).

$\mathrm{UI}$ is often seen as a direct consequence of the aging process. However, it should not be considered "normal". UI depevelops as a result of factors that are external to the urinary tract and more frequent in older people (4). These include changes in motivation, mobility and lucidity, and presence of comorbidities (5).

Although UI does not put people's lives at risk, it can have serious medical, social, psychological and economic implications, adversely affecting quality of life (QoL) (6). Women with UI usually report limitations in physical performance (exercise, carrying of objects), and social, occupational and household disruptions (7).
Their participation in social life becomes dependent on the availability of toilets and they commonly report concern and embarrassment about the smell of urine. They have difficulty during sexual intercourse, as well as sleep disturbances. In addition, they silently experience reduced self-esteem, becoming depressed, anxious and irritated (7).

UI correlates with postural changes that occur over time. These changes may disrupt the pelvis and are caused by factors such as pregnancy, obesity, changes in the physiological curves of the spine, effect of gravity forces, among others. The body then tries to achieve a new balance, often causing damage to other bodily functions (8).

Postural re-education becomes an essential mechanism for continence, because a "statically balanced" pelvis contributes to the maintenance of a correct positioning of the abdominal viscera and a proper functioning of supporting organs, thus favoring the recovery of urinary control (9).

The method of Isometric Stretching is based on balance exercises for body control that correct body postures and lead to greater flexibility and stronger joints, tendons and muscles (10).

It is a global, upright, postural gymnastics method. It is called "postural" because most exercises are performed with the patient at a correct vertical position, over the course of a long expiration. It is called 
"global" because it makes the whole body work, and exercise and relaxation are included in each posture. Finally, it is called "upright" because it causes the spine to self-aggrandize so as to work more specifically the deep paraspinal muscles (10).

Thus, this study aimed to verify the effect of Isometric Stretching on the quality of life of older women with complaint of urinary incontinence.

\section{Materials and methods}

This longitudinal, experimental study was conducted from July 2010 through September 2010 at a long-term care facility in the city of Curitiba, Brazil. The study project was approved by the Research Ethics Committee of the Faculdades Integradas do Brasil (UniBrasil), opinion number 30/2010. All subjects signed the an informed consent form, compiled in accordance with Resolution 196/96 of the National Health Council.

23 older women live in the institution where this study was conducted. Inclusion criteria were: complaint of UI and age equal to or above 65 years. Older women with a history of previous gynecological surgery, diagnosis of urinary tract infection, and cognitive deficits as assessed with the Mini Mental State Examination (11) were excluded from the study. Use of diuretics was not an exclusion criteria. However, all participants who started using diuretics in the course of the study were excluded due to possible effects on symptoms of abstinence. 14 older women met the inclusion and exclusion criteria. In this study, we analyzed the following variables: duration of institutionalization, age, education, race, number and types of deliveries, and type of UI.

We used the International Consultation on Incontinence Questionnaire - Short Form (ICIQ-SF) (12) to assess women's QoL and urinary loss pre- and post-treatment. The ICIQ-SF consists of four questions that assess frequency, severity and impact ofUI, as well as a set of eight self-diagnosis items related to the causes or urinaryincontinence situations experienced by respondents. The final score is the sum of the scores obtained in questions 3, 4 and 5, and is classified into four severity categories: mild (1-5 score points), moderate (6-12 score points), severe (13-18 score points) and very severe (19-21 score points) (13).
The training consisted of 240 -minute sessions a week, on Monday and Wednesday afternoons. The first 10 minutes were allotted for the performance of preliminary 'warming up' exercises (circle dance) (14), in order to prepare participants both physiologically and psychologically to perform the exercises. In the remaining 30 minutes, the group performed eight symmetrical exercises based on the principles of the method of isometric stretching (positions 01, $36,37,38,39,55$, variants 3 and 41 ) in the sitting and standing postures. Each exercise was repeated 6 times (10).

In order to avoid inter-operator variability, all exercises were administered by the same researcher. Corrections were made by two other researchers, who had been previously trained in the use of the method.

\section{Statistical Analysis}

Quantitative data were described as means (Central Tendency Measure) and standard deviations (dispersion measure). The Shapiro-Wilk test was applied to verify the normal distribution of the data. The data that showed normal distribution were compared using Student's t-testand those that did not show a normal distribution were analyzed using the Walsh test, a non-parametric version of Student's $t$-test. The level of significance was set at $p<0.05$ for all statistical tests.

\section{Results}

This study aimed to assess quality of life in older women with urinary incontinence before and after the administration of an exercise program based on the principles of the method of isometric stretching. In order to do so, we used the ICIQ-SF.

We assessed 14 older women with complaint of UI, aged 69-91 years and without cognitive impairment (as measured by the Mini Mental State Examination). However, 4 women (p1, p6, p7, p9) were excluded during the course of the study because they met at least one exclusion criterion: one woman started using diuretics, two had urinary tract infection, and one was unable to perform the exercises due to fracture of the femur.

The 10 older women who completed participation in the study had been institutionalized for a mean of 
5.1 years and had a mean age of 79.8 years. Of these, seven were literate. All participants were White. Their mean number of vaginal deliveries was 6.5. Four women had no pregnancies. Most participants $(70 \%)$ used diapers or sanitary napkins. $60 \%$ had a clinical diagnosis of stress UI, while $40 \%$ had a diagnosis of mixed UI.

The results of the ICIQ-SF are discussed next. For purposes of analysis, we chose to interpret question 5 and the total score. Question 5 refers to the assessment of quality of life through the following question: "Overall, how much does leaking urine interfere with your everyday life?". The total score is used to identify the degree of UI, based on the answers to questions 3 ("How often do you leak urine?"), 4 ("How would you describe the amount of urine you usually leak") and 5.

Figure 1 shows the individual results from question 5 of the ICIQ-SF pre- and post-treatment. This question assesses how much UI interferes with everyday life. Its score ranges from zero to ten, and the assessment is made using a visual analog scale. A score of zero indicates no interference with everyday life, and a score of ten indicates high interference (12). 8 older women (p2, p3, p4, p5, p8, p10, p12, p14) showed improvements in QoL, and 2 (p11, p13) had an unchanged score.
Figure 2 shows the means results from question 5 pre- and post-treatment. The mean score pretreatment was 7.0, while the mean score post-treatment was 3.4. This corresponds to a mean reduction of 3.6 score points. Administration of the exercise program based on the principles of isometric stretching was associated with statistically significant improvemets in QoL ( $\mathrm{p}$-value $=0.011$ ), at a 95\% level of significance.

Figure 3 shows the total individual ICIQ-SF scores pre- and post-treatment. According to pretreatment total score (calculated as the sum of the results from questions 3, 4 and 5), five older women (p5, p8, p11, $\mathrm{p} 13, \mathrm{p} 14)$ had moderate UI and five women (p2, p3, p4, p10, p12) had severe UI.

Upon completion of the treatment program, the final score showed that two women (p3, p5) had no symptoms of UI, one woman (p2) had mild UI, and seven women (p4, p8, p10, p11, p12, p13, p14) had moderate UI. Administration of the exercise program based on the principles of isometric stretching was also associated with statistically significant improvemets in UI ( $p$-value $=0.007061$ ), at a 95\% level of significance.

Table 1 shows the results of question 6 ("When do you lose urine?") of the ICIQ-SF.

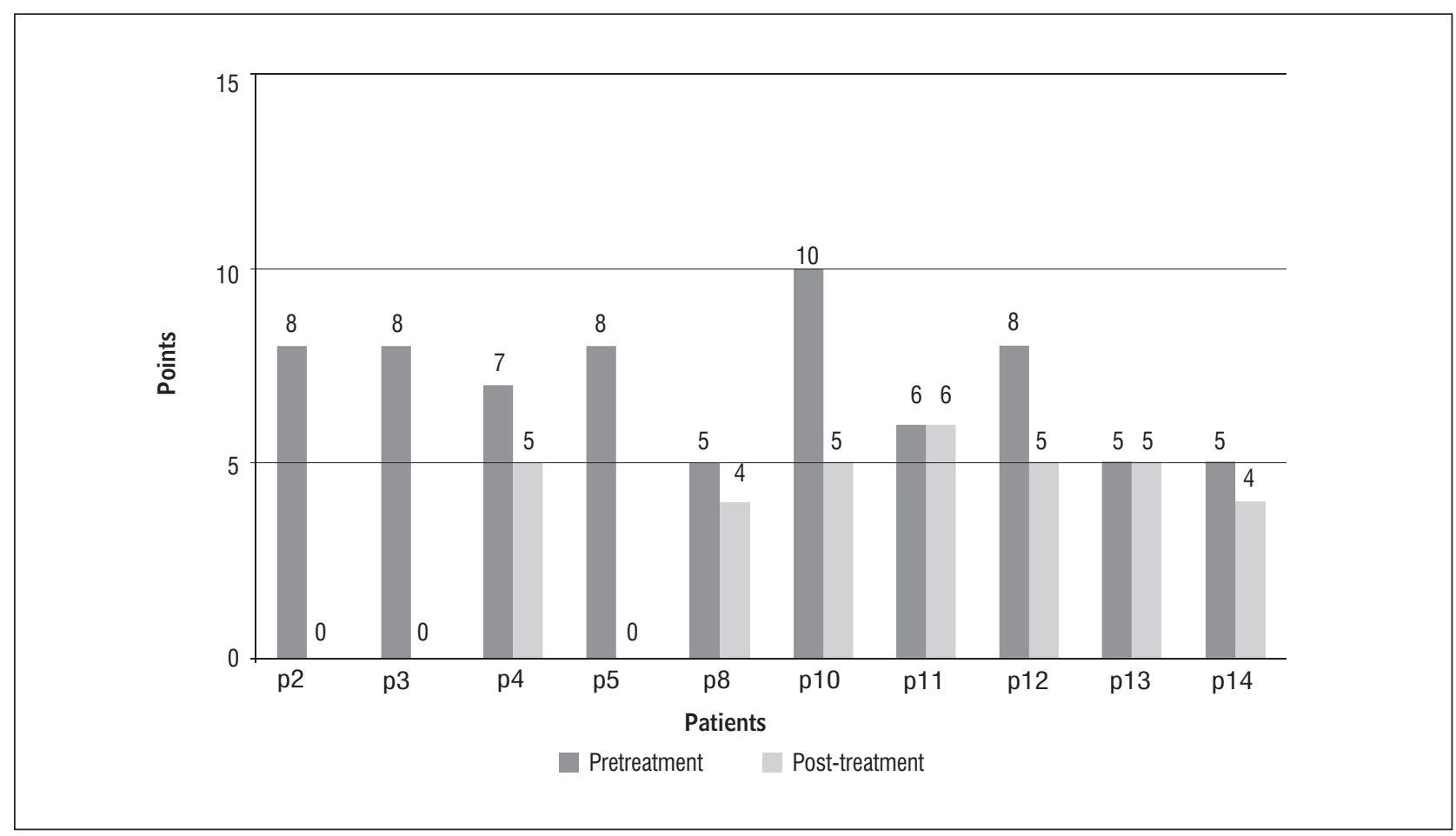

Figure $\mathbf{l}$ - Individual results from question 5 of the ICIQ-SF - pre- and post-treatment Source: research data. 


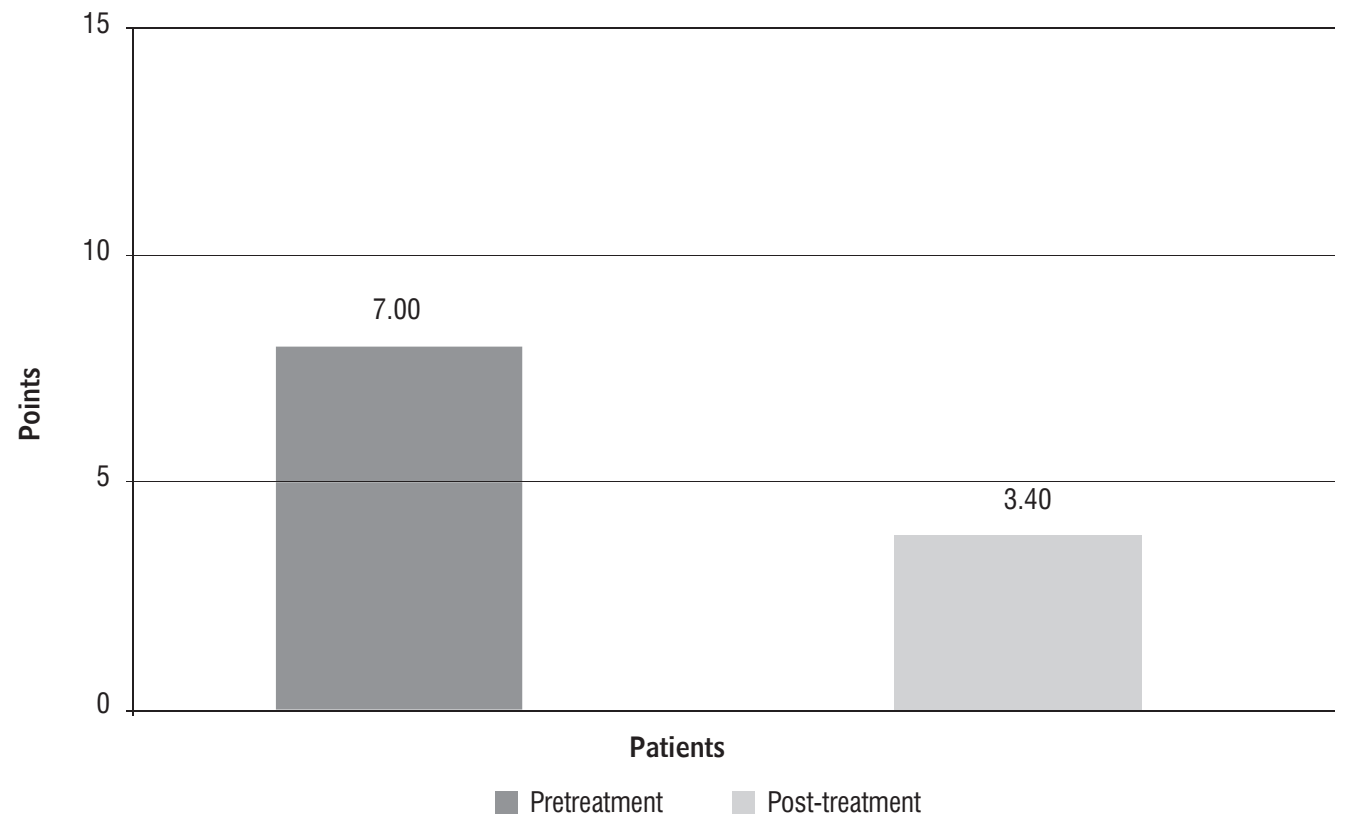

Figure 2 - Mean results from question 5 of the ICIQ-SF - pre- and post-treatment Source: research data.

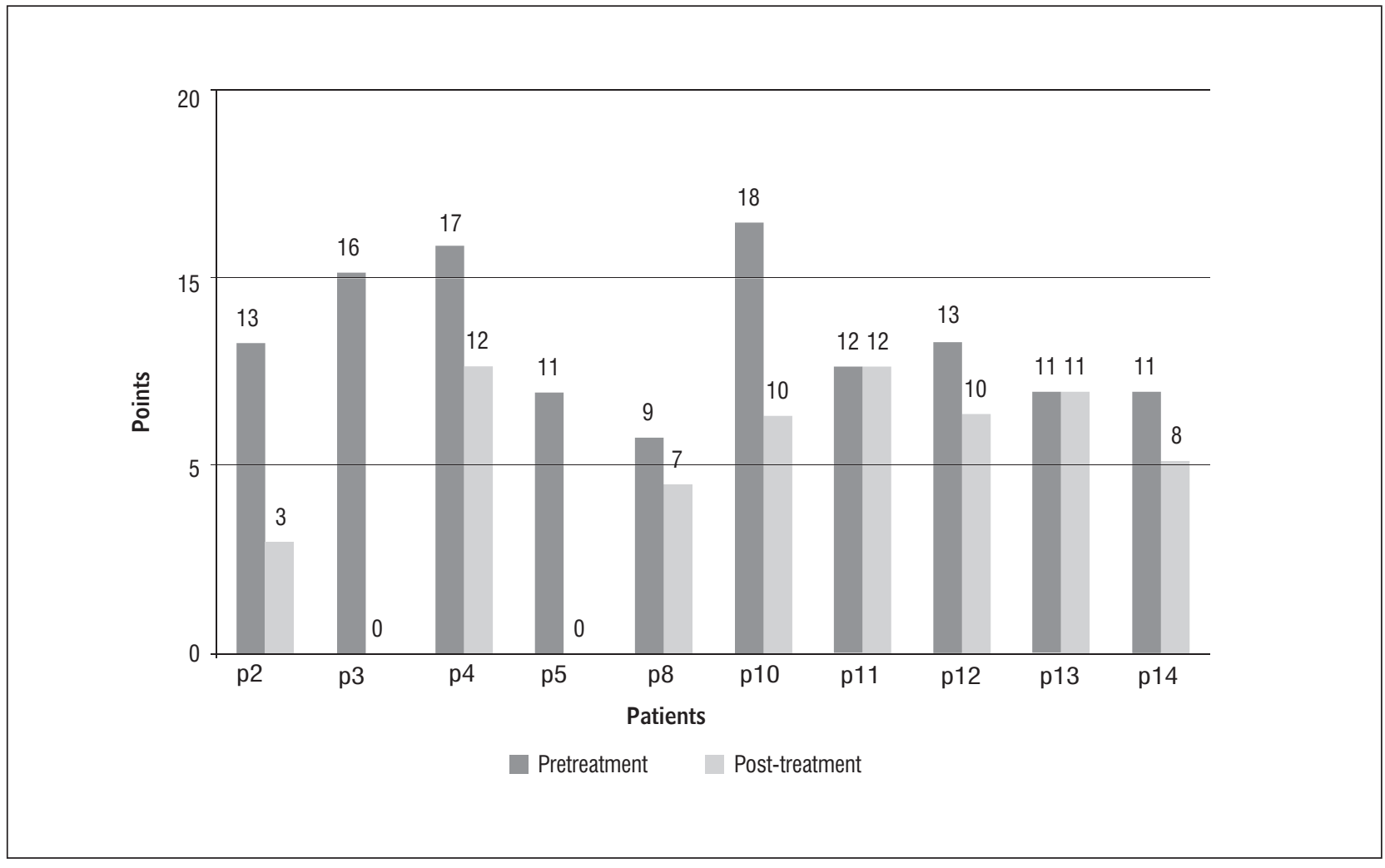

Figure 3 - Total individual ICIQ-SF score - pre- and post-treatment Source: research data. 
Table 1 - Results of question 6 ("When you lose urine?") of the ICIQ-SF

\begin{tabular}{lcc}
\hline \multicolumn{1}{c}{ Urinary loss... } & $\begin{array}{c}\text { Percentage of older women with this } \\
\text { complaint before treatment }\end{array}$ & $\begin{array}{c}\text { Percentage of older women with this } \\
\text { complaint after treatment }\end{array}$ \\
\hline Never & $0 \%$ & $0 \%$ \\
During sleep & $40 \%$ & $30 \%$ \\
While dressing after just & $30 \%$ & $20 \%$ \\
having uninated & $30 \%$ & $50 \%$ \\
Before I can get to the bathroom & $30 \%$ & $20 \%$ \\
During exercise & $10 \%$ & $0 \%$ \\
For no obvious reason & $100 \%$ & $70 \%$ \\
When i cough or sneeze & $10 \%$ & $0 \%$ \\
All the time & & \\
\hline
\end{tabular}

Source: Research data.

\section{Discussion}

In this study, the QoL of incontinent older women was assessed using the ICIQ-SF.

The literature points out that the intensity of UI (mild, moderate or severe) affects the QoL of incontinent women, i.e., the greater the amount of urine loss, the greater the negative effects on QoL (15).

The pelvic floor muscles are made up of: $70 \%$ of type 1 fibers, which have an antigravity function, keeping the tone constant and making it possible to maintain continence at rest; and $30 \%$ of type 2 fibers, which contribute to providing sufficient back pressure for urethral closure during a sudden increase in abdominal pressure (16). Harries and Bassey (17) state that a $15 \%$ decline in muscle strength occurs between the sixth and seventh decades of life, and that there is a $30 \%$ decline of the maximum individual strength every decade of life thereafter. This hypotrophy is most commonly observed in type 2 fibers. Between ages 20 and 80 there is an approximante $26 \%$ decline in these fibers, which would help explain the appearance of UI in older women (18).

Although the aim of this study was not to examine the variations in pelvic floor muscle (PFM) strenghth, we believe that the improvements in continence scores seen in this study correlate with the increase in PFM strenghth as a result of the exercises performed. Moreover, isometric stretching also promotes muscle balance (10). Leon (19) claims that the lack of knowledge about the functioning of the pelvic floor musculature may be a precipitating factor for UI, because the lack of knowledge about muscle function may lead to hypotrophy and weakness. This finding corroborates the study by Oliveira and Garcia (20), who have found that $100 \%$ of participants were unaware of the functioning of the pelvic floor musculature.

The use of exercises that teach patients to contract the pelvic floor muscles correctly are effective in the treatment of patients with UI, because they help improve sphincter control, increase the recruitment of muscle fibers, and stimulate the unconscious, simultaneous contraction of the pelvic diaphragm (21).

According to Moreno (21), repetitive voluntary contractions of the pelvic floor musculature help increase muscle strength and contribute to continence by promoting the activity of the urethral sphincter and a better support of the bladder neck, stimulating reflex contractions of these muscles during stress activities.

Guyton (16) states that during workload exercises focusing on type 2 fibers, there is an increase in the volume of these fibers, i.e., muscle hypertrophy occurs. This causes the urethral closure pressure to remain positive (intra-urethral pressure $>$ intravesical pressure), promoting urinary continence.

Diokno et al. (22) have found that $30 \%$ to $50 \%$ of institutionalized older women had urinary loss or leakage, whereas only $37.7 \%$ of non-institutionalized older women had this complaint. Herzog et al. (23) 
have found that $14 \%$ to $18 \%$ of non-institutionalized older women had UI, versus $45 \%$ of institutionalized older women. These studies corroborate our findings, since 14 of the 23 women who lived in the long-term care facility $(60.8 \%)$ had a clinical diagnosis of UI.

The concept of QoL is related to self-esteem and personal well-being, and covers a number of aspects. Old age is often associated with dependency/autonomy issues. UI causes distress and is a disabling condition that has social consequences to these women $(24,25)$. The repercussions are numerous. For example, incontinent women usually suffer from physical and psychosocial problems that interfere with their social, sexual, family and work lives, causing shame, frustration, embarrassment and fear (15).

The results of this study demonstrate that $80 \%$ of participants improved their QoL scores. This finding corroborates the studies by Zanetti et al. (26) and Sousa et al. (27), who have found a significant increase in the QoL of incontinent patients after 3 months of treatment with pelvic floor exercises. Oliveira and Garcia (20) have conducted a 3-month study using an exercise program for streghthening the musculature of the pelvic floor and found that it was effective in improving the QoL and UI of 11 older women.

Fozzatti et al. (28) concluded that treatment with global postural reeducation (GPR) can also significantly improve UI symptoms and related QoL. Caetano et al. (29) have investigated the effects of a general exercise program including perineal exercises on the QoL of incontinent women, using the ICIQ-SF. After 16 weeks of intervention, all women showed improvements in their QOL and UI. This corroborates the results of this study, in which $80 \%$ of participants showed improvements in UI symptoms, given that, before treatment, five women had been classified as having moderate UI and five as having severe UI, and after treatment two women showed no symptoms of UI, one was classified as having mild UI, and seven were classified as having moderate UI.

QoL perception and UI symptoms remained unchanged before and after treatment for $20 \%$ of patients ( $\mathrm{p} 11$ and $\mathrm{p} 13$ ). This may be due to the fact that they had difficulties understanding the instructions and performing the exercises correctly. This finding corroborates the study by Bastos and Santos (30), who state that motor tasks that are considered relatively simple by young individuals, may not be considered simple by older individuals. This suggests a possible effect of aging on motor behavior. Another factor that may justify this unchanged results is the fact that these two women were the oldest ones and had the longest durations of institutionalization in the sample. It is known that, the longer the duration of institutionalization, the greater the debility of the patient (31).

With regard to question 6 of the ICIQ-SF ("When do you lose urine?"), two patients showed worsening in urine leakage before reaching the toilet. This result does not corroborate the data reported by Rett et al. (7), who have found a decrease in urinary symptoms, particularly urinary frequency, nocturia and urgency. One possible factor that may explain this increase in complaints of urine loss before reaching the bathroom is the cold, because our treatment program was conducted during the winter months. This is in line with the study by Ruoti et al. (32), who claim that exposure to cold air enhances renal response, causing increased diuresis.

\section{Conclusion}

We concluded that Isometric Stretching contributed to a significant improvement in urinary incontinence symptoms and, consequently, in the quality of life of incontinent older women. Thus, this study confirms that kinesiotherapy is beneficial in the treatment of UI symptoms in older women. In addition, it is effective, safe and low cost.

Nevertheless, further studies should be performed with longer treatment durations, larger sample sizes, using individual care plans, and for comparing Isometric Stretching with other postural re-education methods.

\section{References}

1. Wei J, Raz S, Young GPH. Fisiopatologia da incontinência urinária de esforço. São Paulo: Byk; 1999.

2. Abrams P, Cardozo L, Fall M, Griffiths D, Rosier P, Ulmsten U, van Kerrebroeck P, Vitor A, Wein A. The standardisation of terminology of lower urinary tract function: report from the standardization subcommittee of the international continence society. Neurourol Urodynamics. 2002;21:167-78. 
3. Silva L, Lopes MHBM. Incontinência urinária em mulheres: razões da não procura por tratamento. Rev. Esc. Enferm. USP. 2009;43(1):72-8.

4. Freitas F, Menke CH, Rivoire W. Rotinas em ginecologia. Porto Alegre: Artmed; 2002.

5. Reis BR, Cologna AJ, Martins ACP, Paschoalin EL, Tucci SJ, Suaid HJ. Incontinência urinária no idoso. Acta Cirúrgica Brasileira. 2003;18(5):47-51.

6. Lopes MHBM, Higa R. Restrições causadas pela incontinência urinária à vida da mulher. Rev. Esc. Enferm. USP. 2006;40(1):34-41.

7. Rett MT, Simões JA, Herrmann V, Gurgel MSC, Morais SS. Qualidade de vida em mulheres após tratamento da incontinência urinária de esforço com fisioterapia. Rev. Bras. Ginecol. Obstet. 2007;29(3):134-40.

8. Wallach S, Ostergard D. Anatomia pélvica feminina. São Paulo: Atheneu; 2001.

9. Amaro JL, Gameiro M00. Tratamento não cirúrgico da incontinência urinária de esforço. Departamento de Urologia - Serviço de Fisioterapia Faculdade de Medicina de Botucatu, UNESP, 1999.

10. Redondo B. Isostretching: a ginástica da coluna. Rio de Janeiro: Skin Direct Store; 2003.

11. Brucki SM, Nitrini R, Caramelli P, Bertolucci PH, Ivan $H$, Okamoto IH. Sugestões para o uso do mini-exame do estado mental no Brasil. Arq Neuropsiquiatr. 2003; 61(3-B):777-81.

12. Tamanini JTN, Dambros M, D'Ancona CAL, Palma PCR, Junior NRN. Validação para o português do "International Consultation on Incontinence Questionnaire - Short Form" (ICIQ-SF). Rev Saúde Pública. 2004;38(3):438-44.

13. Klovning A, Avery K, Sandvik H, Hunskaar S. Comparison of two questionnaires for assessing the severity of urinary incontinence: The ICIQ-UI SF versus the incontinence severity index. Neurourol. Urodynam. 2009;28:411-15.

14. Ramos RCL. Danças Circulares Sagradas - Uma Proposta de Educação e Cura. São Paulo: Triom; 2002.

15. Butler RN, Maby JI, Montella JM, Yong GGPH. Urinary incontinence: keys to diagnosis of the older woman. Geriatrics. 1999;54(10):29-30.
16. Guyton AC, Hall JE. Tratado de Fisiologia Médica. Rio de Janeiro: Guanabara Koogan; 1997.

17. Harries UJ, Bassey EJ. Torque-velocity relationships for the knee extensors in women in their 3rd and 7th decades. Eur J Appl Physiol Occup Physiol. 1990; 60(3):187-90.

18. Lexell J. What is the cause of the ageing atrophy total number, size and proportion of different fiber types studies in whole vastus lateralis muscle from 15 to 83 age year old men. International Neurology Science. 1988;81:275-91.

19. Leon MIWH.A eficácia de um programa cinesioterapêutico para mulheres idosas com incontinência urinária. Revista Fisioterapia Brasil. 2001;2(2):107-15.

20. Oliveira JR, Garcia RR. Cinesioterapia no tratamento da incontinência urinária em mulheres idosas. Rev. Bras. Geriatr. Gerontol. 2011;14(2):343-51.

21. Moreno AL. Fisioterapia em uroginecologia. Barueri: Manole; 2009.

22. Diokno CA, Brock BM, Brown MB, Herzog AR. Prevalence of urinary incontinence and other urological symptoms in the noninstitutionalized elderly. J Urol. 1986;136:1022-5.

23. Herzog AR, Diokno CA, Fultz NH. Urinary incontinence: medical and psychosocial aspects. Annu Rev Gerontol Geriatr. 1989;9:74-119.

24. Vecchia RD, Ruiz T, Bocchi SCM, Corrente JE. Qualidade de vida na terceira idade: um conceito subjetivo. Rev Bras Epidemiol. 2005;8(3):246-52.

25. Thomas TM, PlymatKR, Blannin J, Mead TW. Prevalence of urinary incontinence. Br Med J. 1980;281:1243-5.

26. Zanetti MRD, Castro RA, Rotta AL, Santos PDS, Sartori M, Girão MJBC. Impact of supervised physiotherapeutic pelvic floor exercises for treating female stress urinary incontinence. São Paulo Med J. 2007; 125(5):265-9.

27. Sousa JG, Ferreira VR, Oliveira RJ, Cestari CE. Avaliação da força muscular do assoalho pélvico em idosas com incontinência urinária. Fisioter Mov. 2011; 24(1):39-46. 
28. Fozzatti MCM, Palma P, Herrmann V, Dambros M. Impacto da reeducação postural global no tratamento da incontinência urinária de esforço feminina. Rev. Assoc. Med. Bras. 2008;54(1):17-22.

29. Caetano AS, Tavares MCGCF, Lopes MHBM, Poloni RL. Influência da atividade física na qualidade de vida e auto-imagem de mulheres incontinentes. Rev Bras Med Esporte. 2009;15(2):93-7.

30. Bastos FH, Santos S. Efeito da prática na consistência de ações motoras em idosos. In: V Seminário Internacional sobre Atividades Físicas para a Terceira Idade, São Paulo, 2002.
31. Santos MLC, Andrade MC. Incidência de quedas relacionada aos fatores de riscos em idosos institucionalizados. Revista Baiana de Saúde Pública. 2005;29(1):57-8.

32. Ruoti RG, Morris DM, Cole AJ. Reabilitação aquática. Barueri: Manole; 2000.

Received: 04/17/2012

Recebido: 17/04/2012

Approved: 06/11/2015

Aprovado: 11/06/2015 
